\title{
HUBUNGAN PENGETAHUAN DENGAN KETRAMPILAN PERAWAT DALAM MELAKUKAN TINDAKAN BANTUAN HIDUP DASAR DI INSTALASI GAWAT DARURAT RSUD YOWARI KABUPATEN JAYAPURA
}

\author{
Anie Irianie Mairuhu ${ }^{1}$, Puji Rahayu ${ }^{2}$, Siti Halima Kastela ${ }^{3}$ \\ ${ }^{1)}$ Mahasiswa S1 Keperawatan STIKes Jayapura \\ ${ }^{2)}$ RSUD Yowari Kabupaten Jayapura \\ ${ }^{3)}$ SMK Negeri 1 Sentani \\ email:ajirahayu03@gmail.com
}

\begin{abstract}
ABSTRAK
Latar Belakang: Bantuan hidup dasar adalah tindakan darurat untuk membebaskan jalan napas, membantu pernapasan dan mempertahankan sirkulasi darah tanpa menggunakan alat bantu. Bantuan hidup dasar biasanya diberikan oleh orang-orang disekitar korban yang diantaranya akan menghubungi petugas kesehatan terdekat. Pertolongan ini harus diberikan secara cepat dan tepat, sebab penanganan yang salah dapat berakibat buruk, cacat bahkan kematian pada korban kecelakaan atau henti jantung. Metode Penelitian: adalah metode deskriptif korelasional Banyaknya jumlah sampel dalam penelitian ini menggunakan sampel minimal yaitu 38 responden dengan kriteria inklusi dan ekslusi. Analisis data berdasarkan presentase dan dideskripsikan dalam tabel distribusi frekuensi. Hasil: Correlation Coefficient sebesar $r=$ 0.458 dengan sig. (2-tailed) adalah $0,004(\square<0.05$ ). Hal ini berarti ada hubungan antara pengetahuan dengan keterampilan perawat dalam melakukan tindakan BHD di RSUD Yowari. Tingkat hubungan antara kedua variabel sebesar (positif) 0.458 , yang berarti kekuatan hubungan berada pada tingkat hubungan sedang, selain itu hubungan bernilai positif ini berarti peningkatan pengetahuan diikuti peningkatan keterampilan perawat dalam melakukan tindakan BHD. Kesimpulan: Bantuan hidup dasar merupakan pengetahuan ataupun keterampilan dasar yang harus dimiliki oleh seorang perawat guna menunjang perannya sebagai provider kesehatan yang profesional. Pengetahuan perawat akan dapat menentukan kualitas dari pelayanan yang akan diberikan, semakin tinggi pengetahuan maka layanan akan semakin berkualitas dan sebaliknya.
\end{abstract}

Kata Kunci : Bantuan Hidup Dasar, Keterampilan Perawat, Pengetahuan

\section{ABSTRACT}

Background: Basic life support is an emergency measure to free the airway, help breathing and maintain blood circulation without using aids. Basic life support is usually provided by people around the victim who will contact the nearest health worker. This help must be given quickly and accurately, because the wrong handling can be bad, disability and even death in victims of accidents or cardiac arrest. Research Method: Use the descriptive correlational method the of samples of recearch in this study uses a minimum sample of 38 respondents with inclusion and exclusion criteria. Analysis is based on percentage and is described in the frequency distribution table. Result: coefficient correlation was $r=0.458$ with sig. (2-tailed) is 0.004 $(\square 0.05)$. This means that there is a relationship between knowledge and nurses' skills in performing Basic life support in Yowari Hospital. The level of the relationship between the two variables is (+ / positive) 0.458 , which means the strength of the relationship is at the level of moderate relations, besides this positive relationship means an increase in knowledge followed by an increase in the skills of nurses in performing Basic life support actions. Conclusion: Basic life assistance is a basic knowledge or skill that must be possessed by a nurse to support 
Anie Irianie Mairuhu : Hubungan Pengetahuan Dengan KeterampilanPerawat

Dalam Melakukan Tindakan BantuanHidup Dasar Di Instalasi Gawat Darurat Rsud

Yowari Kabupaten Jayapura

its role as a professional health provider. Knowledge of nurses will be able to determine the quality of the services that will be provided, the higher the knowledge, the more quality of services and vice versa.

Keywords: Basic Life Support, Knowledge, Nurse Skills

\section{PENDAHULUAN}

Dalam meningkatkan pembangunan kesehatan bagian utama yaitu dalam pelayanan yang bersifat darurat. Untuk mewujudkan peningkatan mutu pelayanan dalam penanganan korban atau pasien gawat darurat diperlukan suatu sistem penanganan korban yang dilakukan secara terpadu dan terintegrasi dengan melibatkan beberapa pihak (Depkes, 2010).

Gawat darurat (Emergency Nursing) merupakan pelayanan keperawatan yang komprehensif diberikan kepada pasien dengan injuri atau sakit yang mengancam kehidupan. Sebagai seorang spesialis, perawat gawat darurat menghubungkan pengetahuan dan keterampilan untuk menangani respon pasien pada resusitasi, syok, trauma, ketidakstabilan multisystem, keracunan dan kegawatan yang mengancam jiwa lainnya (Krisanty, 2009). Sebagai penyedia layanan pertolongan 24 jam, perawat dituntut memberikan pelayanan yang cepat, tepat, dan cermat dengan tujuan mendapatkan kesembuhan tanpa kecacatan. Oleh karena itu, perawat perlu membekali dirinya dengan pengetahuan dan perlu meningkatkan keterampilan yang spesifik yang berhubungan dengan kasus-kasus kegawatdaruratan (Maryuani, 2013). Bantuan hidup dasar adalah tindakan darurat untuk membebaskan jalan napas, membantu pernapasan dan mempertahankan sirkulasi darah tanpa menggunakan alat bantu. Bantuan hidup dasar biasanya diberikan oleh orang-orang disekitar korban yang diantaranya akan menghubungi petugas kesehatan terdekat. Pertolongan ini harus diberikan secara cepat dan tepat, sebab penanganan yang salah dapat berakibat buruk, cacat bahkan kematian pada korban kecelakaan atau henti jantung. Bantuan hidup dasar ditujukan untukmemberikan perawatan darurat bagi para korban, sebelum

pertolongan yang lebih mantap dapat diberikan oleh dokter atau petugas kesehatan lainnya (Sudiatmoki, 2011). Bantuan hidup dasar atau Basic Life Support merupakan usaha yang pertama kali dilakukan untuk mempertahankan kehidupan saat penderita mengalami keadaan yang mengancam nyawa (Guyton \& Hall, 2011). Bantuan hidup dasar merupakan salah satu upaya yang harus segera dilakukan oleh seorang apabila menemukan korban yang membutuhkanya. Oleh karena itu, setiap tenaga kesehatan khususnya perawat wajib menguasainya (Keenan, Lamacraft \& Joubert, 2010).

Menurut Fajarwati (2012) dalam (Parajulee \& Selvajaj, 2013) menyatakan bahwa pengetahuan bantuan hidup dasar dianggap dasar keterampilan untuk perawat keterampilan bantuan hidup dasar menjadi penting karena didalamnya diajarkan tentang bagaimana teknik dasar penyelamatan korban dari berbagai kecelakaan atau musibah sehari-hari yang biasa dijumpai. Saat ini RJP dimulai kompresi dada dengan urutan C-A-B. Namun, pedoman tersebut juga merekomendasikan individualisasi urutan berdasarkan etiologi dari henti jantung. RJP untuk korban tenggelam sebaikanya tetap menggunakan pendekatan A-B-C mengingat sifat hipoksia dari henti jantung tersebut. Korban hanya dengan henti nafas biasanya merespon sestelah beberapa kali pemberian nafas bantuan. Penelitian yang dilakukanoleh (Alhidayat, 2013), menunjukkan bahwa ada hubungan yang signifikan antara tingkat pengetauan perawat Instalasi Gawat Darurat tentang pengkajian primer terhadap tindakkan life support di Rumah Sakit Pelamonia Makasasar. Dari penelitian ini didapatkan bahwa ada 
hubungan yang bermakna antara pengetahuan pengkajian primer terhadap pelaksanaan tindakan life support. Perawat dengan tingkat pengetahuan tentang pelaksanaan tindakan life support yang baik pula.

Hasil penelitian (Lontoh dkk, 2013) menunjukkan adanya pengaruh pada pelatihan teori bantuan hidup dasar pada siswa-siswi SMA tentang RJP (Resusitasi Jatung Paru). Sebagian besar mengalami peningkatan getahuan dari sebelum diberikan pelatihan dan sesudah diberikan pelatihan. Hasil studi pendahuluan yang dilaksanakan peneliti di IGD RSUD Yowari Kabupaten Jayapura, didapatkan data hampir sebagian perawat sudah banyak mengikuti pelatihan BTCLS baik yang diadakan oleh pihak rumah sakit maupun perawat mengikuti kegiatan tersebut di luar rumah sakit. Dalam satu bulan terakhir diruang Instalasi Gawat Darurat banyak kejadian yang dimana pasien sangat membutuhkan penatalaksanaan bantuan hidup dasar. Namun pengetahuan dan tindakan yang dilakukan perawat belum banyak membuahkan hasil dalam menyelamatkan pasien yang membutuhkan bantuan hidup dasar. Hal ini membuktikan masih tingginya angka kematian yang rata-rata untuk setiap bulannya basien meninggal berjumlah 10 pasien dengan berbagai macam diagnosa. Hal ini menunjukkan begitu pentingnya bantuan hidup dasar yang harus dimiliki oleh semua perawat.

Data yang di ambil dari hasil rekapan data pengunjung tahun 2017 yaitu pasien yang datang dan dilakukan RJP sebanyak 131 pasien dengan penyakit interna (penyakit dalam) sedangkan untuk kasus bedah sendiri sebanyak 16 pasien, dimana setelah dilakukan RJP pasien yang dapat diselamatkan selama tahun 2017 sekitar 56 pasien, pasien tersebut ada yang di rawat di ICU dan adapula yang di rawat di ruang perawatan dan juga ada pasien meninggal, sedangkan untuk pasien bedah hampir seluruh pasien yang dilakukan RJPdinyatakanmeninggal. Dari data awal observasi dan wawancara peneliti pada saat studi pendahuluan di Instalasi Gawat Darurat RSUD Yowari Kabupaten Jayapura bahwa jumlah perawat di Instalasi Gawat
Darurat RSUD Yowari berjumlah 38 perawat. Perawat diruang tersebut hanya sekedar tahu bahwa bantuan hidup dasar merupakan salah satu tindakan pertama yang harus segera di lakukan untuk menolong nyawa pasien. Hal ini membuktikan bahwa masih kurangnya pengetahuan dan skill perawat terhadap penatalaksanaan bantuan hidup dasar.

Dari uraian latar belakang di atas maka peneliti tertarik untuk melakukan penelitian dengan judul "Hubungan Tingkat Pengetahuan dan keterampilan perawat dalam melakukan tindakan Bantuan Hidup Dasar di IGD RSUD Yowari Kabupaten Jayapura".

\section{METODE PENELITIAN}

Jenis penelitian ini bersifat descriptif corelational, teknik sampling menggunakan total sampling berjumlah 38 responden. Penelitian ini dilakukan di ruangan IGD RSUD Yowari Kabupaten Jayapura pada bulan Mei hingga Juli 2018. Alat penelitian yang digunakan dalam penelitian ini yaitu dengan menggunakan kuesioner pengetahuan perawat terhadap bantuan hidup dasar berdasarkan konsep AHA 2015 dan keterampilan perawat dalam melakukan bantuan hidup dasar sesuai standar operasional prosedur yang berbentuk ceklist.

\section{HASIL PENELITIAN}

\section{Univariat}

Dalam analisa univariat ini peneliti memaparkan mengenai kriteria responden (umur, jenis kelamin, masa kerja, pendidikan, pelatihan), pengetahuan dan keterampilan perawat dalam melakukan tindakan bantuan hidup dasar. 


\begin{tabular}{lcc}
\hline Keterampila & & \\
n & 18 & 47.4 \\
Terampil & 16 & 42.1 \\
Cukup & 4 & 10.5 \\
Terampil & $\underline{38}$ & $\underline{100.0}$ \\
Kurang & & \\
Terampil & & \\
Total & & \\
\hline
\end{tabular}

Tabel 1 Karakteristik Responden

\begin{tabular}{ccc}
\hline Kriteria & Frekuensi & $\%$ \\
\hline Pendidika & & \\
nD3 & 32 & 84.2 \\
S1 & 6 & 15.8 \\
Total & 38 & 100.0 \\
\hline Pelatiha & & \\
n Ya & 13 & 34.2 \\
Tida & 25 & 65.8 \\
k & 38 & 100.0 \\
Total & & \\
\hline
\end{tabular}

Pada tabel 1 pengelompokan umur diurutkan berdasarkan Departemen Kesehatan tahun 2009. Dari 38 respoden yang diteliti, 34

orang atau $89.5 \%$ diantaranya berusia $26-$ 35 tahun dan 4 orang atau $10.5 \%$ diantaranya berusia $36-45$ tahun. Hal ini menunjukkan bahwa sebagian besar responden berusia antara26-35 tahun.

Kriteria responden berdasarkan jenis kelamin. Dari 38 responden yang diteliti, 13 orang atau $34.2 \%$ diantaranya berjenis kelamin laki-laki dan 25 orang atau $65.8 \%$ diantaranya berjenis kelamin perempuan. Hal ini menunjukkan bahwa mayoritas responden berjenis kelamin perempuan.

Kriteria responden berdasarkan masa kerja. Dari 38 responden yang diteliti, 12 orang atau $31.6 \%$ diantaranya telah bekerja selama 1- 5 tahun, 23 orang atau $60.5 \%$ diantaranya telah bekerja selama 6-10 tahun dan 3 orang atau $7.9 \%$ diantaranya telah bekerja 11-15 tahun. Hal ini menunjukkan bahwa sebagian besar responden telah bekerja selama 6-
10 tahun.

Kriteria responden berdasarkan pendidikan. Dari 38 responden yang diteliti, 32 orang atau $84.2 \%$ diantaranya berpendidikan D3 dan 6 orang atau 15.8\% diantaranya berpendidikan S1 Keperawatan. Hal ini menunjukkan bahwa sebagian besar responden berpendidikan diploma/D3.

Kriteria responden berdasarkan pelatihan PPGD atau BTCLS. Dari 38 responden yang diteliti, 13 orang atau $34.2 \%$ responden telah mendapatkan

\begin{tabular}{lcc} 
Kriteria & Frekuensi & $\%$ \\
\hline Umur & & \\
$26-35$ tahun & 34 & 89.5 \\
36-45 & 4 & 10.5 \\
tahunTotal & 38 & 100.0 \\
\hline Jenis & & \\
Kelamin & 13 & 34.2 \\
Laki-laki & 25 & 65.8 \\
Perempua & 38 & 100.0 \\
$\mathrm{n}$ & & \\
Total & & \\
\hline Masa Kerja & & \\
$1-5$ tahun & 12 & 31.6 \\
$6-10$ tahun & 23 & 60.5 \\
$11-15$ & 3 & 7.9 \\
tahunTotal & 38 & 100. \\
& & 0 \\
\hline
\end{tabular}

pelatihan mengenai bantuan hidup dasar dan 25 orang atau $65.8 \%$ responden tidak mendapatkan pelatihan mengenai bantuan hidup dasar. Hal ini menunjukkan bahwa sebagian besar responden tidak mendapatkan pelatihan mengenai bantuan hidup dasar.

Tabel 2 Pengetahuan dan Keterampilan Perawat

\begin{tabular}{|c|c|c|}
\hline Kriteria & Frekuensi & $\%$ \\
\hline Pengetahua & & \\
\hline nBaik & 32 & 84.2 \\
\hline Cukup & 5 & 13.2 \\
\hline Kurang & 1 & 2.6 \\
\hline Total & $\underline{38}$ & 100.0 \\
\hline
\end{tabular}

Pada tabel 2 diatas menggambarkan pengetahuan perawat dalam melakukan BHD. Dari 38 responden yang diteliti, 32 orang atau $84.2 \%$ diantaranya memiliki pengetahuan baik, 5 orang atau $13.2 \%$ diantaranya memiliki pengetahuan cukup, 
dan 1 orang atau $2.6 \%$ diantaranya memiliki pengetahuan kurang. Hal ini menunjukkan bahwa sebagian besar responden memiliki pengetahuan baik dalam melakukan BHD. Keterampilan perawat dalam melakukan tindakan BHD. Dari 38 responden yang diteliti, 18 orang atau $47.4 \%$ diantaranya memiliki keterampilan terampil, 16 orang atau $42.1 \%$ diantaranya memiliki keterampilan cukup terampil, dan 4 orang atau $10.5 \%$ diantaranya memiliki keterampilan kurang terampil. Hal ini menunjukkan sebagian besar responden memiliki keterampilan terampil dalam melakukan tindakan BHD.

\section{Bivariat}

Uji Rank Spearman digunakan untuk mengetahui hubungan pengetahuan dengan keterampilan perawat dalam melakukan tindakan BHD di RSUD Yowari. Hasil Rank Spearman dapat dilihat pada tabel di bawahberikut:

Tabel 3 Hubungan Pengetahuan dengan Keterampilan Perawat

$\begin{array}{lccl}\text { Var } & \text { Sig. } & \text { Correlat } & \\ \text { iabe } & \text { Taile } & \text { ionCo } & \text { Keter } \\ 1 & \text { d) } & \text { efficie } & \text { anga } \\ & \square & \text { nt } & \mathrm{n} \\ & & \text { Spear } & \\ & & \text { man } & \\ & & \text { rho } & \end{array}$

(r)

\begin{tabular}{lcll}
\hline \multicolumn{1}{r}{ Pen } & & & \multicolumn{1}{c}{ Si } \\
getahua & 0.00 & 0 & gnifi \\
n - & 4 & . & kan \\
Ketera & & 4 & hubu \\
mpilan & & 5 & ngan \\
perawat & & 8 & sedan \\
& & & g \\
\hline
\end{tabular}

Dari tabel 3 diketahui bahwa nilai dari korelasi Correlation Coefficient sebesar $\mathrm{r}$ $=$

0.458 dengan sig. (2-tailed) adalah 0,004 $>0.05$. Hal ini berarti Ho gagal terima artinya ada hubungan antara pengetahuan dengan keterampilan perawat dalam melakukan tindakan BHD di RSUD Yowari. Tingkat hubungan antara kedua variabel sebesar (positif) 0.458 , yang berarti kekuatan hubungan berada pada tingkat hubungan sedang, selain itu hubungan bernilai positif ini berarti peningkatan pengetahuan diikuti peningkatan keterampilan perawat dalam melakukantindakan BHD.

\section{PEMBAHASAN}

\section{Karakteristik Responden}

Pada pengelompokan umur diurutkan berdasarkan Departemen Kesehatan tahun 2009. Dari 38 respoden yang diteliti, 34 orang atau $89.5 \%$ diantaranya berusia $26-$ 35 tahun dan 4 orang atau $10.5 \%$ diantaranya berusia 36- 45 tahun. Hal ini menunjukkan bahwa sebagian besar responden berusia antara 26-35 tahun. Usia berdasarkan WHO meliputi usia pertengahan (middle age) ialah kelompok usia 45 sampai 59 tahun, lanjut usia (elderly) antara 60 sampai 74 tahun, lanjut usia tua (old) antara 75 sampai 90 tahun dan usia sangat tua (very old) usia diatas 90 tahun. Batas usia berdasarkan Depkes RI (2009), yaitu masa balita pada umur 0-5 tahun, masa kanak-kanak pada umur 5-11 tahun, masa remaja awal pada umur 12-16 tahun, masa remaja akhir pada umur 17-25 tahun, masa dewasa awal pada umur 26-35 tahun, masa dewasa akhir pada umur 36-45 tahun, masa lansia awal pada umur 46-55 tahun, masa lansia akhir pada umur 56-65 tahun dan masa manula pada umur 65-sampai atas.

Dengan bertambahnya umur seseorang akan terjadi perubahan aspek fisik dan psikologi (mental), dimana aspek psikologis ini taraf berfikir seseorang semakin matang dan dewasa. Usia seseorang akan mempengaruhi daya tangkap dan pola pikir seseorang terhadap informasi yang didapatkan ataupun yang diberikan. Semakin bertambahnya usia maka daya tanggap dan pola seseorang semakin berkembang dan lebih banyak mendapatkan informasi, selain itu juga semakin cukup umur dan tingkat kematangan serat kekuatan seseorang akan lebih matang dalam menerima informasi serta lebih profesional dalam berfikir dan berkerja (wawan \& Dewi, 2011).

Hasil penelitian dengan kriteria responden berdasarkan jenis kelamin. Dari 38 responden yang diteliti, 13 orang atau 
$34.2 \%$ diantaranya berjenis kelamin lakilaki dan 25 orang atau $65.8 \%$ diantaranya berjenis kelamin perempuan. Hal ini menunjukkan bahwa mayoritas responden berjenis kelamin perempuan sedangkan untuk kebutuhan tenaga kesehatan di Unit Gawat Darurat dan kritis sangat dibutuhkan tenaga laki-laki untuk bekerja banyak tenaga, apalagi jika dalam satu waktu langsung terdapat banyak pasien yang membutuhkan tindakan RJP (Fathoni, 2014).

Hasil penelitian dengan kriteria responden berdasarkan masa kerja. Dari 38 responden yang diteliti, 12 orang atau $31.6 \%$ diantaranya telah bekerja selama 1-5 tahun, 23 orang atau $60.5 \%$ diantaranya telah bekerja selama 6-10 tahun dan 3 orang atau $7.9 \%$ diantaranya telah bekerja 11-15 tahun. Hal ini menunjukkan bahwa sebagian besar responden telah bekerja selama 6-10 tahun. Masa kerja berhubungan juga dengan pengalaman kerja diaman pengalaman adalah suatu kejadian yang pernah dialami oleh individu baik dari dalam dirinya ataupun dari lingkungannya.Pada dasarnya pengalaman mungkin saja menyenangkan atau tidak menyenangkan bagi individu yang melekat menjadi pengetahuan pada individu secara subjektif (Notoatmodjo, 2010).

Hasil penelitian dengan kriteria responden berdasarkan pendidikan. Dari 38 responden yang diteliti, 32 orang atau $84.2 \%$ diantaranya berpendidikan D3 dan 6 orang atau $15.8 \%$ diantaranya berpendidikan S1. Hal ini menunjukkan bahwa sebagian besar responden berpendidikan diploma/D3. Pendidikan berarti bimbingan yang diberikan oleh seseorang kepada orang lain agar mereka dapat memahami. Tidak dapat dipungkiri bahwa makin tinggi pendidikan seseorang maka makin mudah pula bagi mereka untuk menerima informasi, dan pada akhirnya makin banyak pula pengetahuan yang mereka miliki. Kriteria responden berdasarkan pelatihan. Dari 38 responden yang diteliti, 13 orang atau $34.2 \%$ responden telah mendapatkan pelatihan mengenai Bantuan Hidup Dasar dan 25 orang atau $65.8 \%$ responden tidak mendapatkan pelatihan mengenai Bantuan Hidup Dasar. Hal ini menunjukkan bahwa sebagian besar responden tidak mendapatkan pelatihan mengenai Bantuan Hidup Dasar.

Hasil penelitian yang menggambarkan pengetahuan perawat dalam melakukan bantuan hidup dasar. Dari 38 responden yang diteliti, 32 orang atau $84.2 \%$ diantaranya memiliki pengetahuan baik, 5 orang atau $13.2 \%$ diantaranya memiliki pengetahuan cukup, dan 1 orang atau $2.6 \%$ diantaranya memiliki pengetahuan kurang. Hal ini menunjukkan bahwa sebagian besar responden memiliki pengetahuan baik dalam melakukan bantaun hidup dasar.

Pengetahuan adalah hasil dari tahu yang dilakukan oleh manusia terhadap suatu objek tertentu melalui proses penginderaan yang lebih dominan terjadinya melalui proses penginderaan penglihatan dengan mata dan pendengaran dengan telinga. Pengetahuan atau kognitif merupakan dominan yang sangat menentukan dalam membentuk kebiasaan atau tindakan seseorang (over behavior) (Notoatmodjo, 2010).

Pengetahuan itu sendiri dapat dipengaruhi oleh faktor pendidikan formal. Pengetahuan sangat erat hubungannya dengan pendidikan, dimana diharapkan dengan pendidikan yang tinggi maka orang tersebut akan semakin luas pula pengetahuannya. Pengetahuan tidak mutlak diperoleh dari pendidikan formal saja, akan tetapi dapat diperoleh melalui pendidikan non formal. Pengetahuan seseorang tentang suatu objek mengandung dua aspek yaitu aspek positif dan aspek negatif. Kedua aspek ini yang akan menentukan sikap seseorang, semakin banyak aspek positif dan objek yang diketahui, maka akan menimbulkan sikap yang makin positif terhadap objek tertentu. Menurut teori WHO (World Health Organization) yang dikutip oleh Notoatmodjo (2012), salah satu bentuk objek kesehatan dapat dijabarkan oleh pengetahuan yang diperoleh dari pengalaman sendiri (Wawan dan Dewi, 2011). Oleh karena itu seorang perawat 
sangat membutuhkan pengetahuan tentang yang berhubungan dengan dunia medis seperti setiap lima tahun tindakan bantuan hidup dasar selalu terjadi sedikit perubahan sehingga semua perawat harus tahu perubahan tersebut. Selain itu semakin banyak pengetahuan yang dimiliki seorang perawat maka mutu pelayanan akan menjadi semakin baik.

$$
\text { Pada tabel 5.2 diatas }
$$

menggambarkan keterampilan perawat dalam melakukan tindakan bantuan hidup dasar. Dari 38 responden yang diteliti, 18 orang atau $47.4 \%$ diantaranya memiliki keterampilan terampil, 16 orang atau $42.1 \%$ diantaranya memiliki keterampilan cukup terampil, dan 4 orang atau $10.5 \%$ diantaranya memiliki keterampilan kurang terampil. Hal ini menunjukkan sebagian besar responden memiliki keterampilan terampil dalam melakukan tindakan bantuan hidup dasar.Skill atau keterampilan berarti suatu kemampuan dalam mengoperasikan dan melakukan kegiatan secara mudah dan cermat yang membutuhkan kemampuan dasar (basic ability) dalam melakukannya (Robbins, 2010), sedangkan menurut Justine (2016) keterampilan yaitu kemampuan seseorang menerapkan pengetahuan kedalam bentuk tindakkan. Keterampilan seseorang dipengaruhi oleh pendidikan dan latihan (Justine, 2016). Menurut Robbins (2010), keterampilan dibagi menjadi 4 kategori, yaitu: Basic Literacy Skill dimana merupakan suatu keahlian atau kemampuan dasar yang harus dimiliki seseorang dan kebanyakan orang seperti mendengar, membaca serta menulis. Technical Skill menurpakan keahlian secara teknik merupakan keahlian seseorang dalam pengembangan teknik yang dimilikinya melalui berbagai pembelajaran dari menghitung secara tepat hingga melakukan sesuatu kegiatan dengan benar. Interpersonal Skill merupakan suatu kemampuan seseorang dalam berinteraksi dengan orang lain secara efektif dan komunikatif seperti menjadi pendengar yang baik, menyampaikan pendapat, dan dapat bekerja secara kelompok, sedangkan problem skill merupakan suatu kemampuan seseorang dalam mengatasi suatu permasalahan dengan menggunakannya logika. Keterampilan dalam mengetahui penyebab permasalahan, menganalisa dan mengembangkan alternatif serta penyelesaian permasalahan dengan baik.

Faktor-faktor yang dapat mempengaruhi keterampilan menurut Bertnus (2009) yaitu pengetahuan, pengalaman, keinginan/motivasi. Seorang perawat harus memiliki faktor-faktor tertentu yang dapat mempengaruhi keterampilan, hal ini berkaitan dengan tindakan-tindakan yang harus dilakukan untuk membangun suatu keterampilan yang baik. Perawat di Unit Gawat darurat harus memiliki keterampilan yang profesional, keterampilan (kompetensi) khusus tersebut bida didapatkan melalui pendidikan dan pelatihan tentang kegawatdaruratan. Keterampilan tersebut harus selalu ditingkatkan/dikembangkan dan dipelihara sehingga menjamin perawat dapat melaksanakan peran dan fungsinya secara profesional (Musliha, 2010).

Hasil penelitian yang dilakukan oleh Chaundary dan Dave (2011) yang menjelaskan bahwa terjadinya peningkatan keterampilan RJP dapat dilakukan dengan cara mengikuti pelatihan BHD. Pelatihan yang berkesinambungan diperlukan untuk menyegarkan kembali pengetahuan dan keterampilan, sedangkan menurut Joubert(2009) menjelaskan bahwah penyegaran pelatihan harus dilakukan setiap 6-12 bulan untuk mempertahankan kemampuan skill BHD.

Seorang perawat harus memiliki skill yang baik terhadap semua tindakan keperawatan contohnya seperti semua perawat harus mengerti, paham dan juga dapat melakukan bantuan hidup dasar tersebut, dimana tujuannya adalah untuk melakukan pertolongan pertama kepada pasien yang membutuhkan tindakan tersebut. Bantuan hidup dasar ini tidak hanya harus di pahami dan dilakukan oleh perawat yang berdinas di ruang Instalasi Gawat Darurat atau pun ruangan intensif, melainkan semua ruangan yang ada di dalam rumah sakit harus memiliki skill bantuan hidup dasar. Keterampilan yang dimiliki oelh seorang perawat itu tidak serta 
merta langsung memiliki kemampuan tersebut melainkan butuh waktu yang lama untuk membiakan melakukan tindakan medis tersebut, jika sudah terbiasa maka hal tersebut akan dilakukan dengan baik dan benar.

\section{Hubungan Pengetahuan dan Keterampilan Perawat Tentang Bantuan Hidup Dasar}

Hasil penelitian yang dilakukan didapatkan bahwa nilai dari korelasi Correlation Coefficient sebesar $r=0.458$ dengan sig. (2tailed) adalah 0,004 $\square>0.05$. Hal ini berarti Ho gagal terima artinya ada hubungan antara pengetahuan dengan keterampilan perawat dalam melakukan tindakan bantuan hidup dasar di Iinstalasi gawat darurat RSUD Yowari. Tingkat hubungan antara kedua variabel sebesar (positif) 0.458, yang berarti kekuatan hubungan berada pada tingkat hubungan sedang, selain itu hubungan bernilai positif ini berarti peningkatan pengetahuan diikuti peningkatan keterampilan perawat dalam melakukantindakan bantuan hidup dasar.

Bantuan hidup dasar adalah suatu usaha yang dilakukan untuk mempertahankan kehidupan saat penderita mengalami keadaan yang mengancam jiwa dengan cara membebaskan jalan nafas, membantu pernapasan dan mempertahankan sirkulasi darah tanpa menggunakan alat bantu (Goiten, 2010). Bantuan hidup dasar dapat dilakukan oleh tenaga kesehatan maupun yang bukan tenaga kesehatan. Bantuan hidup dasar bertujuan untuk mempertahankan kehidupan manusia, dimana ini merupakan salah satu tugas atau peran dari seorang perawat.

Bantuan hidup dasar adalah suatu usaha yang dilakukan untuk mempertahankan kehidupan saat penderita mengalami keadaan yang mengancam jiwa dengan cara membebaskan jalan nafas, membantu pernapasan dan mempertahankan sirkulasi darah tanpa menggunakan alat bantu (Goiten, 2010). Bantuan hidup dasar dapat dilakukan oleh tenaga kesehatan maupun yang bukan tenaga kesehatan. Bantuan hidup dasar bertujuan untuk mempertahankan kehidupan manusia, dimana ini merupakan salah satu tugas atau peran dari seorang perawat.

Salah satu peran perawat adalah sebagai pemberi asuhan keperawatan. Bantuan hidup dasar merupakan pengetahuan ataupun keterampilan dasar yang harus dimiliki oleh seorang perawat guna menunjang perannya sebagai provider kesehatan yang profesional. Pengetahuan perawat akan dapat menentukan kualitas dari pelayanan yang akan diberikan, semakin tinggi pengetahuan maka layanan akan semakin berkualitas dan sebaliknya.

Pengetahuan merupakan hasil panca indera terhadap obyek tertentu yang dapat mempengaruhi tindakan seseorang. Terdapat enam tingkatan pengetahuan yaitu tahu, memahami, aplikasi, analisis, sintesis dan evaluasi. Untuk menjadi perawat profesional setidaknya harus memenuhi enam tahapan tersebut. Pengetahuan dapat dipengaruhi oleh beberapa faktor diantaranya pendidikan, media massa atau informasi, sosial budaya dan ekonomi, lingkungan, pengalaman, usia dan pekerjaan (Notoatmodjo, 2010). selain itu juga pengetahuan sangat erat hubungannya dengan keterampila dalam melakukan sesuatu, dalam hal ini adalah bahwa ada hubungan yang terjadi antara pengetahuan dengan keterampilan perawat dalam melakukan bantuan hidup dasar pada pasien yang membutuhkan pertolongan.

Hasil penelitian yang dilakukan oleh Rahmat dan Simunati (2013) memiliki perbedaan di dalam klasifikasi tingkat pengetahuan dan keterampilan dimana hasil penelitian tersebut menunjukkan tingkat pengetahuan perawat yang tinggi berpengaruh terhadap keterampilan atau pelaksanaan yang tinggi. Sehingga untuk unit gawat darurat pengetahuan dan keterampilan perawat sangat dibutuhkan terutama dalam pengambilan keputusan klinis dimana keterampilan sangat penting dalam penilaian awal, perawat harus memprioritaskan perawatan pasien atas dasar pengambilan keputusan yang tepat, untuk mendukung hal tersebut dibutuhkan pengetahuan dan keterampilan dalam melakukan tindakan keperawatan. Pengetahuan dan keterampilan perawat 
sangat penting di dalamnya karena perawat merupakan ujung tombak utama dalam sebuah pelayanan khususnya pelayanan di ruang gawat darurat (Oman, 2009).

\section{KESIMPULAN}

Berdasarkan hasil dan pembahasan tentang hubungan pengetahuan dengan keterampilan perawat dalam melakukan tindakan bantuan hidup dasar di instalasi gawat darurat, maka dapat disimpulkan:

1. Pengetahuan perawat dalam melakukan bantuan hidup dasar. Dari 38 responden yang diteliti, 32 orang $(84.2 \%)$ diantaranya memiliki pengetahuan baik, 5 orang $(13.2 \%)$ diantaranya memiliki pengetahuan cukup, dan 1 orang (2.6\%) diantaranya memiliki pengetahuan kurang.

Keterampilan perawat dalam melakukan tindakan bantuan hidup dasar. Dari 38 responden yang diteliti, 18 orang $(47.4 \%)$ diantaranya memiliki keterampilan terampil, 16 orang $(42.1 \%)$ diantaranya memiliki keterampilan cukup terampil, dan 4 orang $(10.5 \%)$ diantaranya memiliki keterampilan kurang terampil.

Hasil penelitian yang ada hubungan antara pengetahuan dengan keterampilan perawat dalam melakukan tindakan bantuan hidup dasar di instalasi gawat darurat RSUD Yowari. Tingkat hubungan antara kedua variabel sebesar (+/positif) 0.458, yang berarti kekuatan hubungan berada pada tingkat hubungan sedang, selain itu hubungan bernilai positif ini berarti peningkatan pengetahuan diikuti peningkatan keterampilan perawat dalam melakukan tindakan bantuan hidup dasar .

\section{DAFTAR PUSTAKA}

American Heart Association (AHA). (2015). Basic Life Support Health Care Provider Pre-tes. Diunduh dari http://www.clinicalnursinginstitue.o $\mathrm{rg} / \mathrm{uploa}$ dedfiles/BJC_HealthCare/If_Health Care_Pro ffesional/Clinic_Nursing_Institute/B
LS. Pada Tanggal 02 Januari 2018.

Alhidayat (2013). Hubungan Tingkat

Pengetahuan Perawat Instalasi

Gawat darurat tentang Pengkajian terhadap Pelaksanaan Tindakan Life Support di Rumah Sakit Pelamonia. Jurnal Makasar. Vol2.No4

Arikunto (2010). Prosedur penelitian Suatu Pendekatan Praktik. Jakarta: Rineka Cipta.

Azwar. (2012). Metode Penelitian. Yogyakarta: Pustaka Pelajar

Alwi \& rasyid. (2010). Gambaran Pengetahuan dan Pelaksanaan. Jakarta:EGC

Bertnus. (2013). Faktor yang Mempengaruhi Keterampilan. Dikutip 2018 Januari 23.Tersedia Dalam $U R L$. http://digilib.unimus.ac.id/files/disk/ 151.

Carles.(2010). Europe Ressusitation Council Guidelines for Resuscitation 2010. Section 4. Adult advanced life support Resuscitation.

Dahlan. (2010). Statistik Untuk Kedokteran dan Kesehatan. Jakarta: Salemba Medika

Depkes RI. (2010). Cara penanganan pasien gawat darurat di IGD. Jakarta: Bina Ilmu

Efendi \& Makhfudii. (2009). Keperawatan kesehatan komunikasi teori dan praktek dalam keperawatan. Jakarta: Salemba Medika

Fajarwati. (2012). Basic Life Support tim bantuanmedis FK UI. Dikutip 2018 Januari dari http://medicine.uji.ac.id/index.php/b erita/Basic-Life-Support-TimBantuan-Medis-FK- UII.html.

Fathoni. (2014). Hubungan tingkat pengetahuan perawat tentang Basic Life Support (BLS) dengan perilaku perawat dalam pelaksanaan primary survey di RSUD dr.Soedirman Mangun Sumarso. Vol 1. No 1

dari Guyton \& Hall. (2011). Buku Ajar Fisiologi Kedokteran. Edisi 11 Jakarta: EGC Hidayat. (2015). Metode Penelitian dan Teknik Analisa Data. Surabaya: Salemba medika 
Hardisman. (2014). First Aid: pertolongan Pertama

Edisi Kelima. Jakarta: Penerbit Erlangga Lontoh. (2013). Pengaruh Pelatihan teori Bantuan

Hidup dasar Terhadap
pengetahuan Resusitasi Jantung
Paru Siswa-Siswi
Toili. JMA Negeri 1
Vol.1.No.1

Jumaidi. (2014). Pedoman pertolongan pertama yang harus dilakukan saat gawat darurat medis. Yogyakarta: Penerbit Andi

Krisanty. (2010). Asuhan Keperawatan Gawat Darurat. Jakarta: Trans Info Medika

Keenam, Lamacraf \& Joubert. (2010). A survey of nurse basic life support knowledge anf training at a teriary hospital. Africa Journal Of Health Proffesions Education, 1 (1) 4-7

Kusnanto. (2013) Pedoman pertolongan pertama yang harus dilakukan saat gawat darurat medis. Jakarta: EGC

Maryuani. (2013). Asuhan

Kegawatdaruratan. Jakarta: Trans Info Media

Muslimah. (2010). Hubungan pelatihan life support dengan pelaksanaan primary survey pada perawat di IGD RSUD dr. Moerwadi Surkadi. Surakarta: Universitas Sahid

Notoatmodjo. (2012). Metodologi Penelitian Kesehatan. Jakarta: Rineka Cipta

Nursalam. (2014). Konsep dan Penerapan Metodelogi Penelitian Ilmu Keperawatan. Jakarta: Salemba Medika

Parajulee \& Selvajaj. (2011). Hubungan Tingkat Pengetahuan dengan Keterampilan Melaksanakan Prosedur tetap isap lendir/saction di ruang ICU RSUD Prof. Dr. Margono Soekarjo Purwokerto. Jurnal Keperawatan. Vol. 2. No.1

Riwidikto. (2011). Statistik Kesehatan. Yogyakarta:Mitra Cendikia Press

Robims. (2010). Pelayanan kesehatan masyarakat.

Kedokteran Jakarta: EGC

Rifiani \& Sulaimam. (2013). Penentuan rute optimal menuju lokas

pelayanan gawat darurat

berdasarkan waktu tempuh

tercepat. Surakarta: Universitas

Sebelas Maret

Suwigyo. (2011). Jaminan Mutu Layanan Kesehatan. Jakarta; EGC

Saryono. (2013). Pendidikan kesehatan dalam keperawatan. Jogyakarta: Nuha Medika

Setiadi. (2013). Pendidikan kesehatan DalamKeperawatan. Jogyakarta: Nuha Medika

Sugiono. (2011). Metode Penelitian Kuantitatif danKualitatif. Bandung: Alfabeta

Sudiatmoki. (2011). Pendidikan kesehatan dalamkeperawatan. Yogjakarta: Nuha Medika Sudoyo. (2010). Konsep gawat darurat dasar.

Yogyakarta: Publing

Wawab \& Dewi. (2011). Teori dan Pengukuran Pengetahuan, Sikap dan Perilaku. Yogyakarta: Muha Medika

Wahid. (2011). Keperawatan Gawat darurat.

Yogyakarta: Nuha Medika Yulianti Sari. (2013). Pengaruh pelatihan teori bantuan hidup dasar terhadap pengetahuan resusitasi jantung paru siswa-siswa SMA Negeri 1 Tolli. 